Supporting Information:

\title{
DNA Tetrahedron Based Biosensor for Argonaute2 Assay in Single Cells and Human Immunodeficiency Virus Type-1 Related Ribonuclease H Detection in Vitro
}

Kai Zhang, ${ }^{*}, \dagger$ Wanting Huang, ${ }^{\dagger}$ Yue Huang, ${ }^{\ddagger}$ Hao Li, ${ }^{\S}$ Ke Wang,${ }^{\dagger}$ Xue Zhu, ${ }^{\dagger}$ Minhao Xie, $*, \dagger$

$\dagger$ Key Laboratory of Nuclear Medicine, Ministry of Health, Jiangsu Key Laboratory of Molecular Nuclear Medicine, Jiangsu Institute of Nuclear Medicine. Wuxi, Jiangsu 214063, China.

College of Light Industry and Food Engineering, Nanjing Forestry University, Nanjing, Jiangsu 210037, China

${ }^{\S}$ School of Biological Science and Technology, University of Jinan, No. 106 Jiwei Road, Jinan, Shandong 250022, China

* Corresponding author. Fax: +86-510-85508775; Tel: +86-510-85508775

E-mail addresses: zhangkai@jsinm.org (K. Zhang), xieminhao@jsinm.org (M. Xie) 


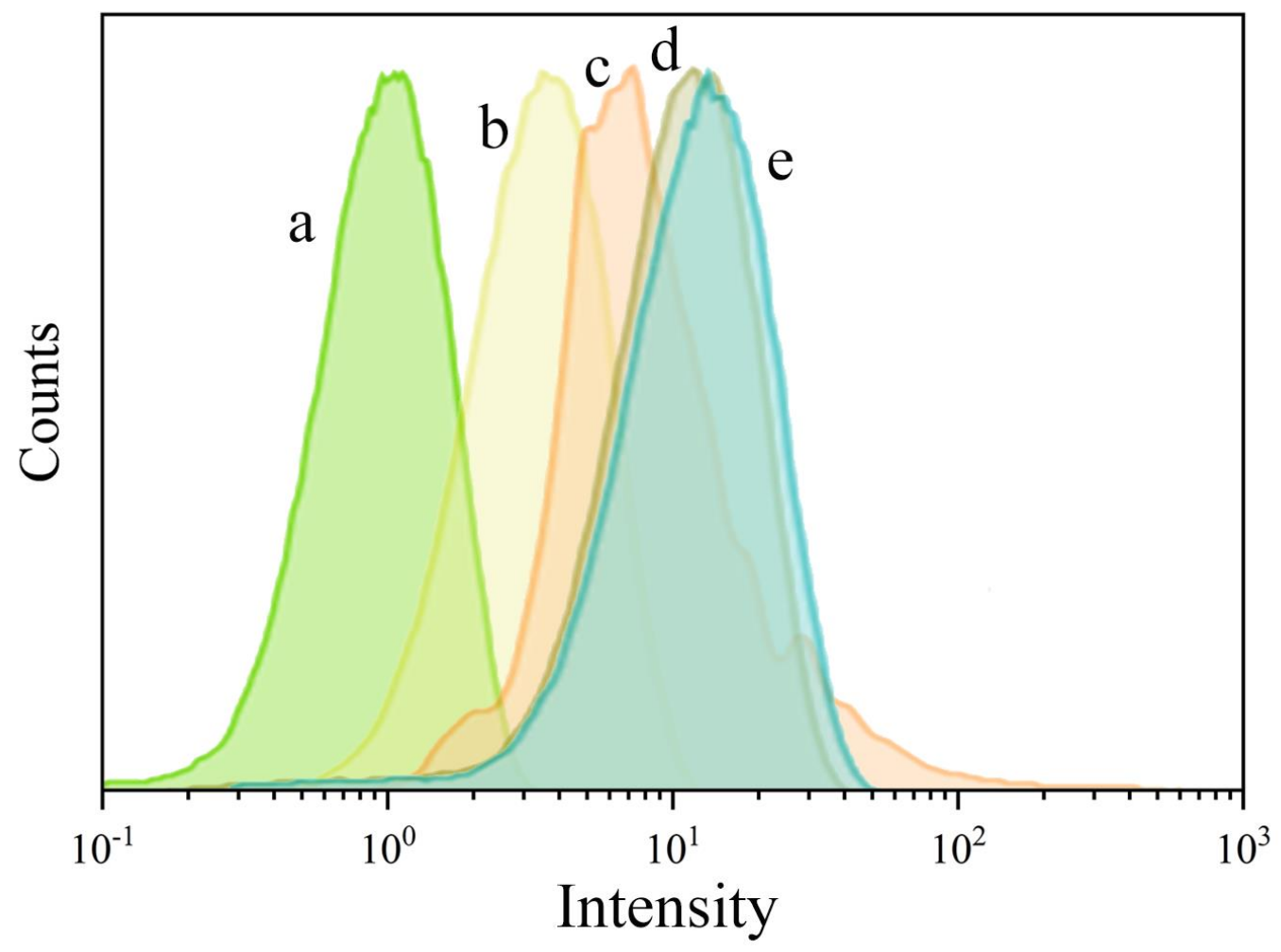

Figure S1. Flow cytometry detection of HeLa cells $\left(0.5 \mathrm{~mL}, 1 \times 10^{6} \mathrm{~mL}^{-1}\right)$ using our DTB for $4 \mathrm{~h}$ incubation with different volumes: (a) $0 \mu \mathrm{L}$, (b) $5 \mu \mathrm{L}$, (c) $10 \mu \mathrm{L}$, (d) $25 \mu \mathrm{L}$ and (e) $50 \mu \mathrm{L}$. 

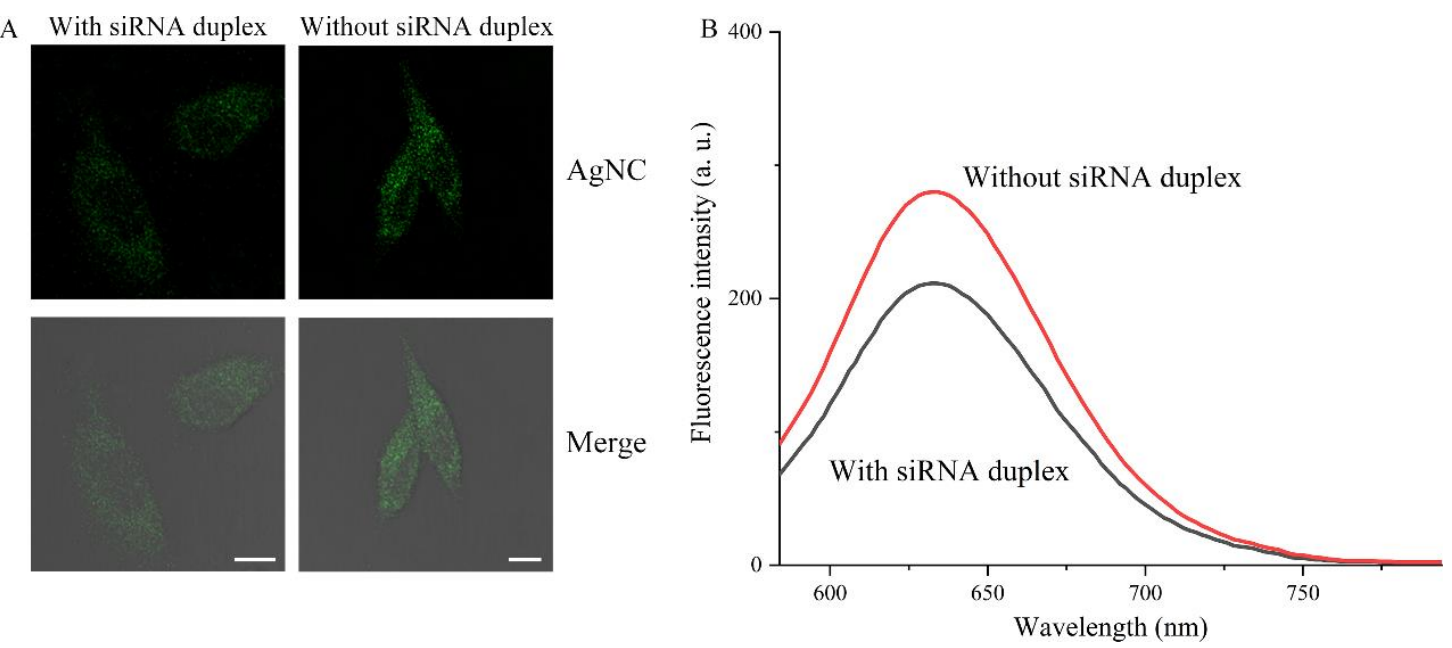

Figure S2. Ago2 knockdown assay. (A) Confocal images of HeLa cells: with a) and without treatment of $0.1 \mathrm{nM}$ siRNA duplex, then incubated with $25 \mu \mathrm{L}$ of DTB for $4 \mathrm{~h}$ (scale bar $25 \mu \mathrm{m}$ ). (B) Fluorescence intensity in cell lysis with siRNA duplex treated and without siRNA duplex. 


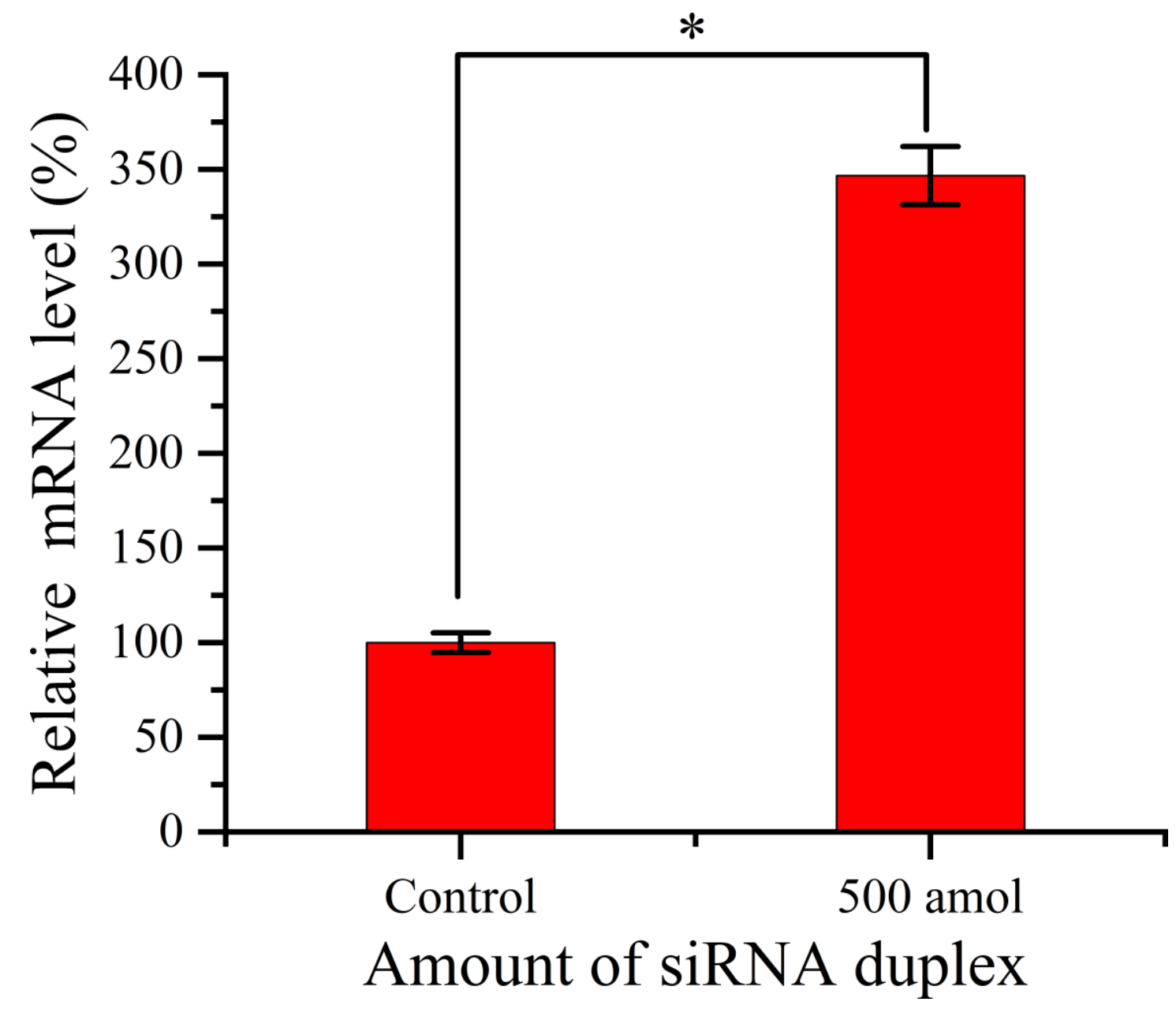

Figure S3. RT-qPCR analyses of c-Myc mRNA expression in the HeLa cells treated with siRNA duplex or control (without siRNA duplex). Each bar presents the mean and standard deviation derived from three independent experiments: Student's t test, *: $\mathrm{P}<0.043$. 
HEK293
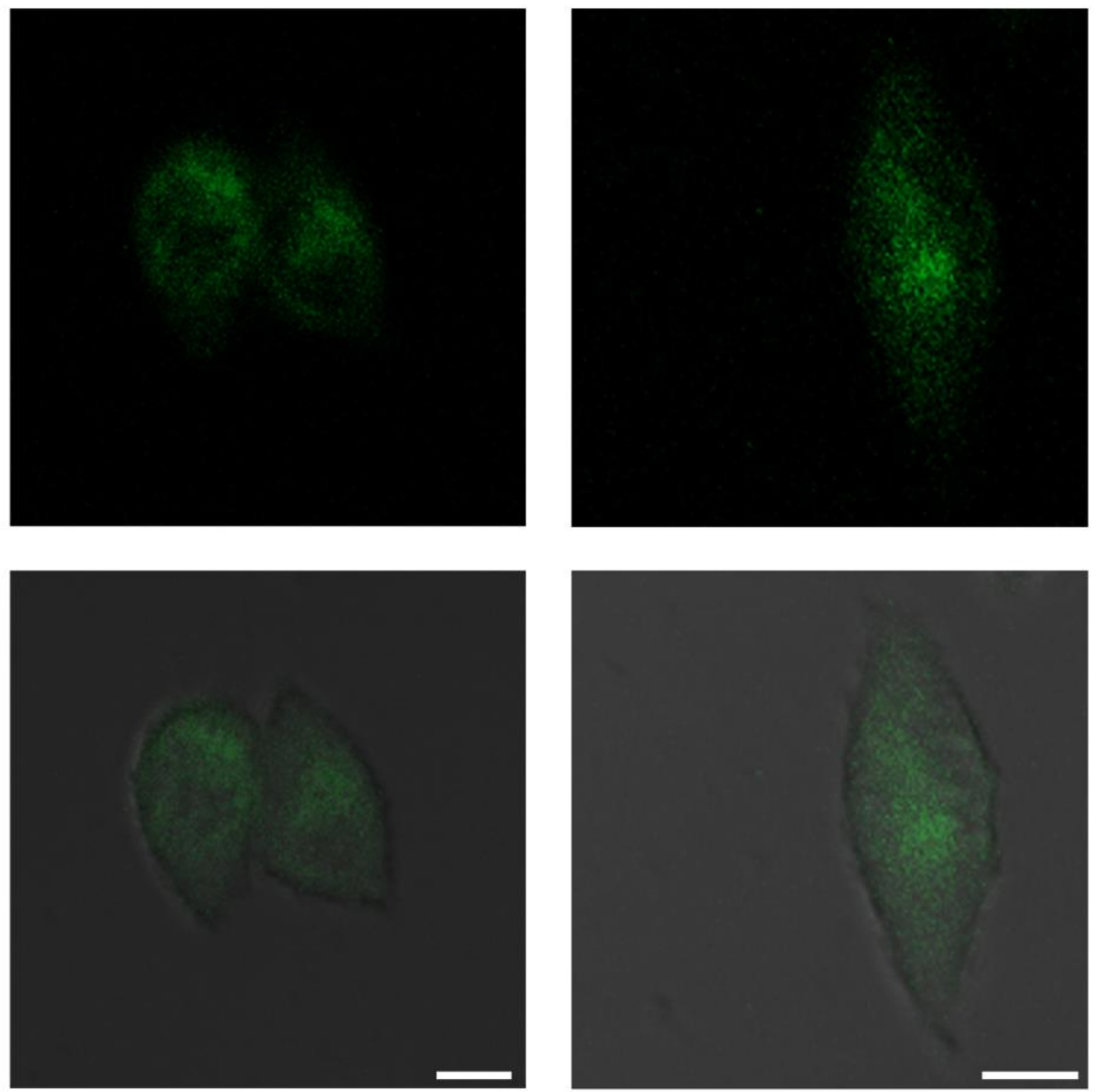

Figure S4. Confocal images of HEK293, and LO2 cells after incubation with $25 \mu \mathrm{L}$ of probe for 4 $\mathrm{h}$ (scale bar $25 \mu \mathrm{m})$. 
Table S1. Comparison of the analytical performance for the detection of Ago2 by using our DTB and other reported literature.

\begin{tabular}{lccc}
\hline \multicolumn{1}{c}{ Strategy } & $\begin{array}{c}\text { Detection } \\
\text { Modes }\end{array}$ & $\begin{array}{c}\text { Detection } \\
\text { limit }\end{array}$ & Reference \\
\hline Oligo modified nanoprobe & Fluorescence & $0.2 \mathrm{nM}$ & 1 \\
G-quadruplex-hemin complexes & Electrochemistry & $5.02 \mathrm{nM}$ & 2 \\
DNA tetrahedron based biosensor & Fluorescence & $4.54 \mathrm{nM}$ & This \\
& & & report \\
\hline
\end{tabular}

Table S2. Comparison of the analytical performance for the detection of RNase H by using our DTB and other reported literature.

\begin{tabular}{lccc}
\hline \multicolumn{1}{c}{ Strategy } & $\begin{array}{c}\text { Detection } \\
\text { Modes }\end{array}$ & Detection limit & Reference \\
\hline Gold nanoparticle & Colorimetric & $27 \mathrm{U} \mathrm{mL}^{-1}$ & 3 \\
$\begin{array}{l}\text { Light-Switching Excimer Beacon } \\
\mathrm{Tb}^{3+} \text {-induced }\end{array}$ & Fluorescence & $5 \mathrm{U} \mathrm{mL}^{-1}$ & 4 \\
$\begin{array}{l}\text { conjugates } \\
\text { DNA tetrahedron based biosensor }\end{array}$ & Fluorescence & $3.41 \mathrm{U} \mathrm{mL}^{-1}$ & This \\
& & & Feport \\
\hline
\end{tabular}

\section{REFERENCE}

1. Zhang, K.; Yang, X.-J.; Zhao, W.; Xu, M.-C.; Xu, J.-J.; Chen, H.-Y., Regulation and imaging of gene expression via an RNA interference antagonistic biomimetic probe. Chem. Sci. 2017, 8, 4973-4977.

2. Yang, N.; Cao, Y.; Han, P.; Zhu, X.; Sun, L.; Li, G., Tools for Investigation of the RNA Endonuclease Activity of Mammalian Argonaute2 Protein. Anal. Chem. 2012, 84, 2492-2497.

3. Xie, X.; Xu, W.; Li, T.; Liu, X., Colorimetric Detection of HIV-1 Ribonuclease H Activity by Gold Nanoparticles. Small 2011, 7, 1393-1396.

4. Chen, Y.; Yang, C. J.; Wu, Y.; Conlon, P.; Kim, Y.; Lin, H.; Tan, W., Light-Switching Excimer Beacon Assays For Ribonuclease $\mathrm{H}$ Kinetic Study. Chembiochem 2008, 9, 355-359.

5. Wu, K.; Ma, C.; Liu, H.; He, H.; Zeng, W.; Wang, K., Label-free fluorescence assay for rapid detection of RNase $\mathrm{H}$ activity based on $\mathrm{Tb}^{3+}$-induced $\mathrm{G}$ quadruplex conjugates. Anal. Meth. 2017, 9, 3055-3060. 